\title{
Diplomacy in the Digital Age
}

\section{Dr. Amany Essam Mohammed Lecturer at Department of Political Science, Faculty of Commerce and Business, Helwan University}

\begin{abstract}
Digital diplomacy is currently perceived as a cardinal direction in diplomatic communication within the new century that is resulting from globalization and new public diplomacy. In light of the developments of information and communication technology, perceiving diplomacy and diplomatic relations have been witnessing radical changes, which paved the way to new digital diplomacy based on these new technologies. Research on this new form of diplomacy, however, rests on scant empirical footing. This paper is an attempt to fill this gap by answering the question: can digital diplomacy establish an appropriate international environment commensurate to international footholds and greater facility in the attainment of national interests?

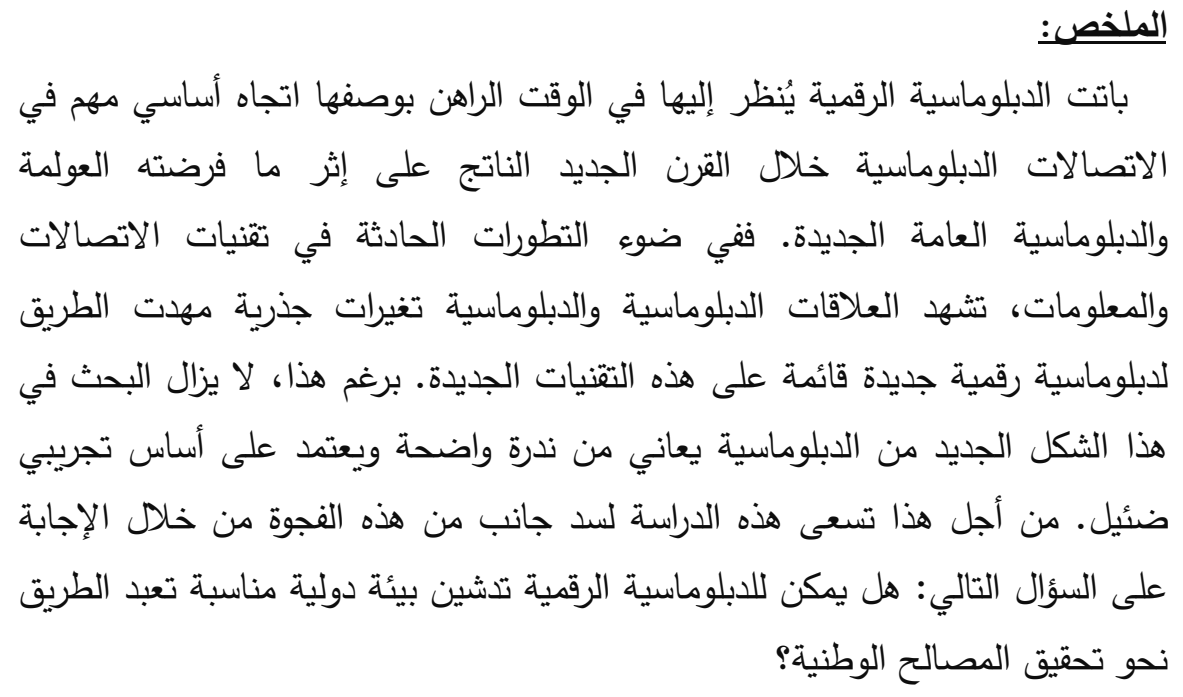

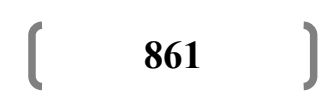


مجلة وادي النيل للاراسات والبحوث الإنسانية والاجتماعية والتريوية (مجلة علمية محكمة)

(ISSN : 2536 - 9555)

\section{Introduction;}

Governments are currently in the process of drafting new forms of diplomacy which can be perceived as pivotal for international relations. With the development of modern society, new scenarios of international relations emerge and require novel techniques to handle. As a prerequisite for communication among various nations, the diplomatic practice continues to exist and to grow to fulfill the constant changes in the national as well as international interests. One of these changes was the rebalancing of the significance of both hard powers based on military or economic status and soft power that takes the form of diplomatic persuasion and influence. There are several changes that have opened the way for these changes, including the unprecedented economic interdependence among nations, the dissemination of cultural aspects of globalization, the movements aimed at empowering public opinion, and the great strides made in information and communication technology that resulted in deepening of the worldwide flow of cultures, ideas, and information.

All this has placed considerable strain on governments and called for the need for the reformulation of the existing policy structures with other countries, particularly in terms of developing new forms of diplomacy to respond adequately to

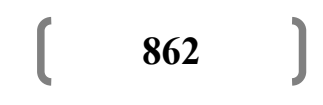



in order to the pursuit of their goals, national governments have to establish their diplomacy attitudes through informing and influencing foreign audiences.

\section{Problem of the study;}

The technology used for data transfer and sharing usually results in the dissemination of disinformation rather than the provision of public diplomacy support. With the evolution of widespread online platforms that have the potential to host various kinds of events and conferences, diplomats are now more capable of using different forms of social media to deliver information as well as to communicate with state and non-state stakeholders. This means that diplomat capacity in using digital technology has become a must and criterion for success.

Besides, in light of the developments of information and communication technology, perceiving diplomacy and diplomatic relations have been witnessing radical changes, which paved the way to new digital diplomacy based on these new technologies. Digital diplomacy is currently perceived as a cardinal direction in diplomatic communication within the

\section{$(863)$}


new century that is resulting from globalization and new public diplomacy. Research on this new form of diplomacy, however, rests on scant empirical footing. The paucity of quality research on digital diplomacy does not allow for definitive claims regarding its origins and evolution, the requirements for implementing effective and successful digital diplomacy, the main benefits and risks, how digital diplomacy can be used to fulfill security, economic and political goals, how it can complement traditional forms of diplomacy, the advantages of direct communication with a foreign audience, and how to use digital diplomacy to establish appropriate international settings commensurate to international footholds and greater facility in the attainment of national interests. This paper is an attempt to fill these gaps.

\section{Questions of the study;}

In light of the above, an attempt was made to address the problem of this study by answering the following research questions:

1. What is the concept of digital diplomacy?

2. How has digital diplomacy evolved?

3. What are the requirements for implementing effective and successful digital diplomacy?

4. What are the main benefits and risks of digital diplomacy?

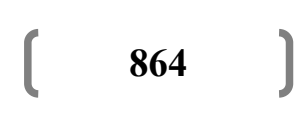


مجلة وادي النيل للاراسات والبحوث الإنسانية والاجتماعية والتربوية (مجلة علمية محكمة)

5. How can digital diplomacy be used to fulfill security, economic and political goals

6. In what ways can digital diplomacy complement traditional state-to-state diplomacy?

7. What are the advantages of direct communication with foreign audiences through digital diplomacy?

8. Can digital diplomacy establish an appropriate international environment commensurate to international footholds and greater facility in the attainment of national interests?

\section{Aims of the study;}

This study aimed at achieving the following aims:

- To identify the concept of digital diplomacy, its definitions, and goals.

- To explain how digital diplomacy has evolved.

- To examine the requirements for implementing effective and successful digital diplomacy.

- To identify the main benefits and risks of digital diplomacy.

- To investigate how digital diplomacy can be used to fulfill security, economic and political goals

- To identify the ways through which digital diplomacy can complement traditional state-to-state diplomacy.

- To identify the advantages of direct communication with the foreign audiences through digital diplomacy.

To investigate if digital diplomacy can establish an appropriate international environment commensurate to

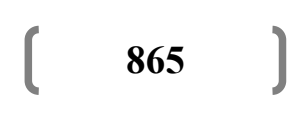


مجلة وادي النيل للاراسات والبحوث الإنسانية والاجتماعية والتريوية (مجلة علمية محكمة)

(ISSN : 2536 - 9555)

international footholds and greater facility in the attainment of national interests.

\section{Methodology of the study;}

A descriptive-analytic approach was used in this study commensurate to its aims. The approach was based on a systematic review of the literature and relevant documents to the area of the study with the purpose of outlining historical data to identify patterns or meaning that would contribute to achieving the aims of this study.

\section{Taxonomies of Digital Diplomacy;}

Recently scholars have devoted a substantial amount of attention to the investigation of digital diplomacy. These efforts have resulted in several categorizations for classifying digital diplomacy. The following paragraphs provide a brief explanation for these categories.

The first category concerns what can be called "the changing foreign policy environment" the significance of this particular category is the unprecedented increased speed of events. This includes to what extent these events are developing in an accelerated way, and their destination and

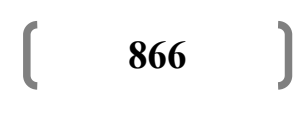


مجلة وادي النيل للاراسات والبحوث الإسانية والاجتماعية والتربوية (مجلة علمية محكمة) orientation. In addition, it is concerned with the potential implications for policymakers. It is worth observing that these notions are familiar as a component of the predominant globalization discourse, and are enhanced by means of the individuals and groups' new ability to shape events through the use of modern ICT tools and services. This means that the ability of governments to disseminate digital resources has become a fundamental condition to go along with the new virtual community.

Added to that, another significant element that would determine how governments will cope with these changes is their ability to control this changing policy environment through developing their capacity to govern the new technology and social networking. Furthermore, the changing character of the policy agenda, especially the increased social power is another determinant to a government's ability to develop agendas in novel ways of policymaking based on the new dynamics of this digital era.

These views on digital diplomacy propose low levels of control over events and agendas. They also point out the need to enhance new skills and make necessary adjustments for the current ones. These changes, then, will have implications on

\section{$\left(\begin{array}{ll}867\end{array}\right)$}


(ISSN : 2536 - 9555)

public diplomacy, which means that diplomats are required to adapt to these changing conditions and the emerging online, technology based-environment, and acquire the necessary knowledge, skills, and competencies so that they can perform their work appropriately.

It is worth considering that networks have the main influence on ideas, not the traditional forms of power, which manifests the increased significance of developing policy agendas in the specific areas appropriate to this trend, such as focusing on human rights, environment, and health topics. This, in turn, emphasizes the importance of knowledge leadership as a critical factor affecting digital resources. The dissemination of news and ideas via social media and modern networking has a profound impact on both individuals and organizations that use the internet as their primary channel for communication.

The second category of digital diplomacy is related to the setting or the environment in which it occurs, i.e. the cyber agendas. Cyber agendas cover the issues of cyber governance, warfare, and security as well as internet freedom. This dimension however is basically technology-based and thus is beyond the scope of this study.

\section{$(868)$}


مجلة وادي النيل للاراسات والبحوث الإسانية والاجتماعية والتربوية (مجلة علمية محكمة)

The third category in the taxonomies of digital diplomacy is concerned with the employment of the internet and ICT tools and products in knowledge management. The significance of this particular category stems from the fact that governments, in light of the knowledge age and the enormous proliferation of information, need to manage data effectively. In the last decade of the twentieth century, the concept of virtual diplomacy has emerged as a result of increased requirements for diplomatic services after the end of the cold war. This has led to a partial change in international relations and gave rise to thinking in new patterns of diplomatic representation instead of, or complementary to, traditional embassy. A major factor in these technologies was the emergence of secure e-mail, which enhanced the arguments questioning the age-old balance between headquarters and diplomatic posts. This influence served to challenge the classical hierarchical work procedures in diplomacy organizations.

The fourth category of the process of digitalizing government work in general, and diplomacy in particular highlights the use of digital technology to enhance the delivery of services, improve the major functions of public

\section{$(869)$}




\section{مجلة وادي النيل للاراسات والبحوث الإنسانية والاجتماعية والتربوية (مجلة علمية محكمة)}

(ISSN : 2536 - 9555)

service sectors, and increase the engagement in policymaking. On one hand, the main point in this respect is to increase access to government and improve participation, which manifests the earlier debates concerning democratizing diplomacy. The issue, then, in the debate is the development of public diplomacy and how this would achieve the expectations of dual communication and the attitude to opening up of the foreign policy processes.

On the other hand, using new channels for communication to manage networks and to carry out the various service functions in an efficient manner, such as what takes place in crisis management.

The very notion of developing a new form of diplomacy that is more responsive; in other words, the second generation of diplomacy retains high visibility on the agenda of digital diplomacy. These notions acknowledge the need to abandon the traditional, hierarchical structures of disseminating information to adopt more interactive patterns of communication.

In brief, the above-mentioned explanations of digital diplomacy serve as significant characteristics of the complicated political environment nationally as well as on the worldwide levels ${ }^{1}$.

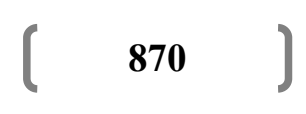


مجلة وادي النيل للاراسات والبحوث الإنسانية والاجتماعية والتربوية (مجلة علمية محكمة)

\section{Digital disruption and diplomacy;}

Digital technologies have recently resulted in the emergence of a persistent issue in the discourses of public diplomacy, that is the debate the speaking against listening, also known as the first generation of public diplomacy versus the second generation of public diplomacy. The differentiation lies in the top-down models of public diplomacy models and dialogue-based models that include the exchange of information and dual-channel communication between the representatives of the public and governments. Multiple opportunities can be allowed through the expansion of digital communication resources. At the same time, several challenges are posed on governments as well various international stakeholders. This is a two-faced coin.

Positively, this provides the ability to reach a huge audience without the need for means of mass communication coverage. Moreover, this allows the ability to segment audiences and send messages directly more accurately. In the listening pattern, however, digital diplomacy presents the possibility to take advantage of the resources of big data in developing policies in a more effective fashion. On the other hand, there is a downside to this process, that is the skills

\section{$\left(\begin{array}{lll} & 871\end{array}\right)$}


needed are no longer only in the hands of the government, rather anyone can improve these competencies necessary for using digital platforms for communication.

The challenges facing governments due to the domination of ICT tools, epically with respect to the dissemination of social networking use, are not limited to the substantial flow of information that is greatly facilitated by the Internet and modern technology, but also the concerns of losing control. The image of a government within this domination of digital world communications is no more under its complete control, but there are other parties contributing to shaping this image. It is worth observing, however, that the imagined control of its image was never under the complete control of any government since there are other actors and stakeholders, such as pressure groups, pressure groups, civil society organizations, and non-governmental organizations who had always manipulated or influenced reputation a long time before the emergence of social networking and opening the world via digital communication tools. All what these technologies did was adding a new challenge to the list of the existing ones.

This is a key influence of the power of social networking and digital communication. The production of big, dominant

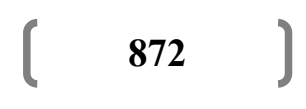


مجلة وادي النيل للاراسات والبحوث الإنسانية والاجتماعية و التربوية (مجلة علمية محكمة) narratives is not controlled by diplomacy anymore, with the new power of digital communications that adds a new dimension and at the same time, an added challenge to shaping and delivering issues in a communicative text. ${ }^{2}$

\section{Public diplomacy:}

Public diplomacy refers to a new area that has been recently receiving increased attention in the digital debate. The advancements in social media have resulted in multiple opportunities for public diplomacy. Nevertheless, these advancements are not limited to taking advantage of social networking sites and platforms for carrying out public diplomacy services. Rather, digital technology holds great potential to diplomacy yet to be explored. ${ }^{3}$

The capacity of a government to put its agendas and narrative for various events is currently facing real challenges resulting from the dramatic transformations in the nature and flow of communications. The old fashion hierarchical perspective of information delivery from a government to the public by means of classical media as a mediator are now threatened by the power of social media that disseminates 


\section{مجلة وادي النيل للاراسات والبحوث الإنسانية والاجتماعية والتربوية (مجلة علمية محكمة)}

(ISSN : 2536 - 9555)

information and engages the public in this process in several ways.

At the levels of a governmental, the public may get access to information from the websites and social media pages of the foreign ministries, while local embassies can compete with host governments, sending messages to particular groups challenging the framing of events given by the host government.

In light of the various types of traditional and nontraditional news organizations, the arena of shaping and delivering news and information is now more complicated. The choice of the factors constituting the news as well as the access to information is now facilitated and delivered through several modalities. Furthermore, the accelerated progress of social media contributes to forming new gatekeepers who can challenge and even alter the traditional role played by media.

For instance, freelancers committed to this new form of journalism, such as bloggers and leaders of social media have the abilities and competences to compete mass media organizations and attract their audience, thus being with real impact on explaining the reality and the media image. ${ }^{4}$ In order to adapt to these radical changes, diplomats have to

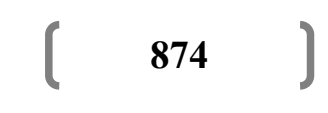


Diplomacy in the Digital Age

Dr. Amany Essam Mohammed

مجلة وادي النيل للاراسات والبحوث الإسانية والاجتماعية و التربوية (مجلة علمية محكمة) adhere to the classical patterns of public diplomacy, and at the same time engage in social media to deliver their messages. ${ }^{5}$

\section{$\underline{\text { Consular diplomacy: }}$}

The challenges associated with consular are thought of as significant challenges at the beginning of the digital era. This is because citizens ask government for given help and services that fulfil the human and society's technological criteria, which are necessary for this type of diplomacy. The archaic term "consular affairs" is not used any more to identify what is going on, returning to the status of a world that is not happening where consular and diplomatic issues are isolated from each other.

Consular diplomacy is intertwined with other fields undertaken by the ministries of foreign affairs in each country, including economic diplomacy, public diplomacy, and development aid. Indeed, diversity in consular performance is likely to have a significant impact on bilateral relations. Examples of political frictions raised by consular cases are several, and high profile cases may gain a great attention at home. Different parties and stakeholders are convinced that consular services are a fundamental task of the government; it

\section{$\left(\begin{array}{lll} & 875\end{array}\right)$}




\section{مجلة وادي النيل للاراسات والبحوث الإنسانية والاجتماعية والتربوية (مجلة علمية محكمة)}

(ISSN : 2536 - 9555)

is the arena of diplomatic work in which the technological difficulties are obviously evident. Consular work within foreign ministries is not new, however it represents currently the top form of interaction with the public. With regard to the estimates of staff, the departments of consular are perceived as the largest sector in the majority of foreign ministries. ${ }^{6}$

With the increased complex modes of international relations, the tasks of consular are increasing as well, and the implications are tested for diplomats. In addition to the increased numbers of demands, the provision of consular services has been an indicator of legitimacy. In the face of growing technologically empowered citizens, the government's failure to respond promptly to crisis situations as well as to meet the public's and media's expectations of support for the citizens now trapped in them has become a test of diplomatic effectiveness; a real test that governments. Moreover, consular work adds further demands on rare diplomatic resources.

In the context of working to address these problems, the ministries of foreign affairs believe in the the need to make quick wins in order to digitize public information on travel as well as provide more customer-specific advice. The obvious solution consular is to design a website, provide automated

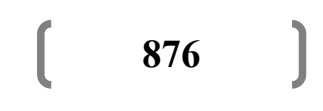


services to citizens traveling, and take advantage of social media in emergency and crisis situations ${ }^{7}$.

Many governments are currently providing continuous daily services and communicating through usual channels like call centers and social media. On the other hand, face to face contact with citizens who convert to customers is focused on different options made available by smart phones. Mexico is a leading country in providing service for citizens via a phone application fifty consulates in one country. In the United States of America invests in online magicians who offer advice ranging from passport inquiries, traveling with children, and emergency services. Blue sky thinking about consular services, with the help of developments in the field of big data, has novel scenarios, where it is not just about people, but also about tracking their possessions by means of GPS tracking. however in light of the recent developments of technology, forecasting future developments is not realistic.

Two digital challenges related to communication and another one related to the attitude towards more cooperative diplomacy was set out in the 2013 Wilton Park Report on Trends in Consular Practice. To begin with, the first challenge is concerned with the expectations of citizens about

\section{$(877)$}


quick solutions as well as the capacity to take advantage of the technology for consular services while offering direct assistance if needed. The next challenge is related to the fact that consular officials think that citizens shall need to communicate with government officials on social networking sites. This can be viewed in cases of governments using such modalities in emergency cases. However, individual officials who help persons in distress are reluctant to reveal their identity by means of using their personal accounts when performing their work.

The concern for ministries of foreign affairs is the transition from a fixed "log" approach, to interactive, ondemand information, rapid organization, and crowd-derived intelligence. Using smart applications that encourage persons to appreciate these applications when they are used may give benefits to the users and the owners of information. Dual channel communication through social networking allows the opportunity to ministries of foreign affairs to have insights from citizens and at the same time help increase the knowledge of citizens in various relevant issues, particularly in emergency situations. ${ }^{8}$ Moreover, there is another aspect of innovation in consular work related to partnership between the public and private actors; such as making arrangements with

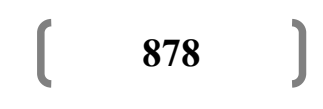


the information and communication technology private sector to make use of their products, tools, and services.

Paying attention to the needs of citizens abroad needs a digital literacy which can be fully afforded by the Ministry of Foreign Affairs, and thus calls for a well-developed 24-hour consular administration that is completely different from other areas of diplomatic activity. Added to that the ethical considerations, privacy concerns and several concerns associated with the digitalization of consular diplomacy. This, in turn, sheds light on the other social aspects as well as the various influences of technological advancements on diplomacy as a social institution.

\section{Digitalization, the national diplomatic system and}

\section{the Ministry of Foreign Affairs;}

Discussions on efficiency and legitimacy calls for thinking of the Ministry of Foreign Affairs in the wider scope of national diplomatic systems. In other words, considering the departments and agencies engaged in the formation and implementation of international policy. The nature of the national development strategy manifests two dominant trends in the management of foreign policy, these are: fragmentation

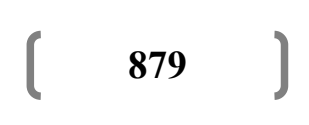


as ministries involving sectors gain enhanced international functions and focus that reflects the significance of central agencies, especially the offices of the Prime Minister and the Presidency. This means that the Ministry of Foreign Affairs may be perceived as a differentiated subsystem of national diplomatic systems with two main components: the center and the diplomatic network or peripheries.

A recent OECD study points out the responses of governments to social networking, especially in terms of the absence of a comprehensive strategy:

few national governments in OECD countries have a dedicated strategy or overarching plan for institutional use of social media. Among those governments that do, most consider social media as being mainly an additional tool to improve public communications. Only a few governments try to genuinely leverage social media for more advanced purposes like involving citizens in public policy processes of transforming and redesigning public service delivery. ${ }^{9}$

The challenges facing the management of foreign policy in the digital era can be viewed as manifestations of theses confronting a government as a whole. Thus, digitization has influence on the relations between the components of the national diplomatic system, including diplomacy, defense, and

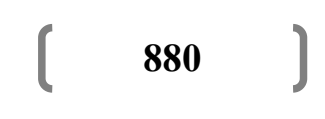


مجلة وادي النيل للاراسات والبحوث الإنسانية والاجتماعية و التربوية (مجلة علمية محكمة) development. Thus, among the concerns of the Ministries of Foreign Affairs in its national situation, which preceded the digital agendas, is its relation with different components of the government as well as the effects of modern communications tools. Information and communication services and tools made available reinforce links between the main elements of the national diplomatic system, however in fragmented foreign policy bureaucracy they raise further essential questions as well, such as questioning on the key actors responsible on deployment to control global narratives. An obvious example of this "the special force of Facebook warriors" established by the government of England who are skillful persons with necessary psychological and technological competences to engage in unconventional warfare in the information age. ${ }^{10}$

In order to point out this growing consensus, the following paragraphs tries first to identify to what extent the task of informing and educating foreign populations can favorably influence the international context and secondly, to reflect how digital diplomacy can help advance specific goals. 
مجلة وادي النيل للاراسات والبحوث الإنسانية والاجتماعية والتريوية (مجلة علمية محكمة)

(ISSN : 2536 - 9555)

\section{Benefiting States in the International Arena;}

The key philosophy underlying digital diplomacy is to engage foreign audiences in an atmosphere of trust and empathy; to establish an empowering international conjuncture, and to enhance the attainments of national interests.

\section{Generating an Atmosphere of Trust;}

In dissemination of information and their cultural values beyond the limits of their national boundaries to the wider regional and international levels, countries think that they are working on promoting their interests. According to Deutsh, the policy of spreading country-specific ideological propaganda in other countries and the launching of policies to support different forms of cultural, scientific and other forms of cooperation are directly linked to the interests of each State. ${ }^{11}$ Many leaders see the promotion of a set of norms and values that they are believed to be favored by society and the world at large as one of the fundamental goals at the national level. ${ }^{12}$ 
مجلة وادي النيل للاراسات والبحوث الإسانية والاجتماعية والتريوية (مجلة علمية محكمة)

\section{Engaging with Key actors and Creating a}

\section{Facilitating Conjuncture.}

In the context of seeking to target the citizens of other States; not only the general public, but also opinion leaders and public figures, public diplomacy allows countries to communicate with the actors of these states and influence their government directly as well as in implicit ways. Before the proliferation of telecommunications tools that make digital diplomacy available in this era, Hans Morgenthau argued for the possibility of this hidden diplomacy that aims at conquering and controlling the minds of citizens rather than conquering territories or controlling economic life. ${ }^{13}$

As perceived by the specialists of diplomacy, this approach may result in various outcomes. An example of these outcomes is getting acquainted with own country. Another examples include establishing a positive attitude of the country, and empowering individuals to understand the policy of their countries ${ }^{14}$. Therefore, the process of making foreign masses have the same vision of the world is thought of as an implicit tool putting pressure to the government. This is because mass and digital diplomacy allow a specific state to 
(ISSN : 2536 - 9555)

secure the consent of its partners through adjusting the will of important components of its population.

The above statement is further indicated by the premise that if there was primary resistance from the part of the target government, this would take place by means of public diplomacy where new alliances can be formed with groups at the national level to try to change policies ${ }^{15}$.

Some politicians and decision makers note that during the provision of foreign audiences with a more enhanced understanding of a specific country, the processes of cultural exchange become a must in order to construct "a corps of informed opinion leaders in the national political, economic, cultural, and social infrastructures of their countries". ${ }^{16}$ The influence of diplomacy in its various forms, including digital diplomacy is highlighted when it is aimed at targeting individuals who have further impact within society. In a similar vein, the core point of the ability of mass diplomacy is taking advantage of the promising and current societal leaders on cultural and ideological issues ${ }^{17}$.

Another prerequisite for achieving this success is establishing information initiatives and strategic communications programs tailored for influential foreign public figures like journalists, state officials, and leaders of

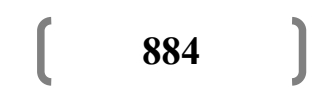


مجلة وادي النيل للاراسات والبحوث الإنسانية والاجتماعية و التربوية (مجلة علمية محكمة) public ${ }^{18}$. This is the reason that make communicating directly with foreign audiences become a major duty of the international policy in the new century. ${ }^{19}$ Furthermore, an added common assumption is that through constructing harmonious relations that are founded on trust and sympathy from both parties, mass diplomacy would enhance the diplomatic situation, and makes a country positioned in a better international place. Through taking advantage of these emotional relations, state will thrive even more by gaining an easy location makes it to attract international public opinion towards the national interest of that state and to twist out the shape of international issues for its own benefit. There is no doubt that using public diplomacy will not alone result in making other governments be willing to collaborate. Public diplomacy has the potential, however, to alter the setting underlying the debate, which leads to effect that is negligible at the scale of outcome ${ }^{20}$.

\section{Using the soft power of diplomacy;}

Digital diplomacy serves as a vehicle for enhancing the interests of a country nationally as well as at a global scope. ${ }^{21}$ This is due to the fact that digital and mass forms of 
diplomacy can promote the position of a certain country or organization on the international level and help it achieve its goals. For instance, a country like Canada uses its soft power, that takes the form of mass diplomacy, to have a real influence on the international scope even though it does not have much to consider in terms of hard power assets. ${ }^{22}$ It is also believed that digital diplomacy can be used aa means for enhancing and disseminating the image and the values of a country, thus leading to protect its interests. ${ }^{23}$

In other words, countries, through the soft powers of digital diplomacy, have the potential to enhance their international standing and have further influence than they are actually capable of. This is evident in the grand strategy of 'alldimensional opening up axe' adopted by Chinese officials with the purpose of serving their long-term national goals ${ }^{24}$. Another example of this is apparent in the India diplomatic strategy which is based on gaining international understanding and attempting to play a central role for the defense of its national interests. ${ }^{25}$ Likewise, other countries, such as Turkey, Iran, and Italy make use of their cultural heritage to enhance their various interests ${ }^{26}$. 
Diplomacy in the Digital Age

Dr. Amany Essam Mohammed

مجلة وادي النيل للاراسات والبحوث الإنسانية والاجتماعية والتربوية (مجلة علمية محكمة)

Digital diplomacy as a tool for more secure, prosperous, and ideologically friendly world

Despite the importance of various aims targeted by diplomacy in general and digital diplomacy in particular, security is always a top priority for any country. In this respect, it is argued that culture, information and communication are strategic assets for establishing and enhancing effective digital diplomacy that underlines the security policy. ${ }^{27}$ Therefore, the issues of transparency, moral legitimacy and accountability to foreign populations serve as key factors to the success of a country defense and security policies. $^{28}$

\section{Digital diplomacy as a tool for serving economic interests.}

With industry 4.0 era, many countries can use digital diplomacy to promote their influence and increase competitiveness ability in the current world. This is due to the fact that recent technological advancements have been altering the domestic as well as the international conditions of countries. ${ }^{29}$ Therefore, a country can make use of digital diplomacy "to shape favorable macroeconomic structures by influencing political and economic leaders into adopting norms and practices that they view as preferable for their own

$$
\text { ( } 887 \text { ) }
$$


economy and for the world economy in general". ${ }^{30}$ It also serves as a viable means for informing populations and "promoting a culture of mass consumption". ${ }^{31}$ Moreover, the cultural aspect of diplomacy would add to the efforts to prevent humanitarian crises through the provision of needed education, ${ }^{32}$ and to stabilize partner countries to have appropriate environments for investment ${ }^{33}$. Digital diplomacy has the potential as well to contributing to international trade policy via opening foreign markets and stimulating exports. ${ }^{34}$

\section{Digital diplomacy as a tool for enhancing political} influence.

Digital diplomacy can have a pivotal role in the dissemination of a political system at the regional and international levels. This may take place by using digital diplomacy in the dissemination of democracy ${ }^{35}$ and the democratic regime, ${ }^{36}$ by globalizing the country's own values and culture, ${ }^{37}$ by targeting foreign populations trough campaigns aimed at spreading democracy, ${ }^{38}$ by considering democracy diplomacy to expand moral influence of the country, ${ }^{39}$ and by promoting a form of democracy that is based on the social values of the country. ${ }^{40}$

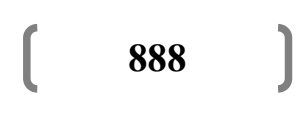


مجلة وادي النيل للار اسات والبحوث الإنسانية والاجتماعية والتربوية (مجلة علمية محكمة)

\section{The risks of digital diplomacy}

Despite the benefits and advantages offered by digital diplomacy, there are many concerns and considerable risks that may be posed by the increased employment of digital diplomacy tools and services. Foremost among these concerns are unchecked freedom in using the internet and social media, which may lead to, or be accompanied with, profound influence on negative events ${ }^{41}$. The internet can also be used as a means for the spread of extremism and terrorism as well as helping various extremist organizations to mobilize constituencies to their values and aims. ${ }^{42}$ The various voices raised through the internet and digital communication tools may diminish a country's control over the process of decisionmaking due to the expressed different security scenarios publically. ${ }^{43}$ Moreover, each country should take the necessary precautions against the external threats that may be online. $^{44}$

Another significant risk associated with digital diplomacy is the lack of knowledge about the usage of the internet and social media, which calls for ongoing training and practice for those in charge of this form of diplomacy. ${ }^{45}$ Added to that the lack of consensus among various countries

\section{$\left(\begin{array}{ll}889\end{array}\right)$}


on how to maintain their internal order and protect themselves in the face of external threat ${ }^{46}$. Nevertheless, living in a globalized world makes this requirement very difficult even for the powerful states ${ }^{47}$, since criticizing the globalized world is more or less criticizing the digital world. Therefore, the officials and diplomats of different ministries of foreign affairs along with civil society organizations need to work together to promote a global discussion on the issues of digital ethics. $^{48}$

\section{Conclusion}

The attempt was made in this study to explore the potential of digital diplomacy to establish an appropriate international environment commensurate to international footholds and greater facility in the attainment of national interests. The core reason behind that was the premise that digital diplomacy, as a result of globalization and new public diplomacy, is considered a cardinal direction in diplomatic communication within the twenty-first century. The advancements taking place in information and communication technology call for considerable alteration of diplomacy and diplomatic relations. This, in turn, calls for a digital form of diplomacy commensurate to the requirements of the current

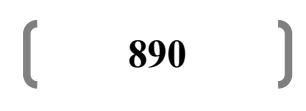


مجلة وادي النيل للاراسات والبحوث الإنسانية والاجتماعية والتربوية (مجلة علمية محكمة) age. This paper conducted a systematic review for this demanding issue, highlighting the different dimensions that would affect or be affected by digital diplomacy. These included the taxonomies of digital diplomacy; digital disruption and diplomacy; consular diplomacy; the digitalization process and its relation to the national diplomatic system as well as the Ministry of Foreign Affairs; the benefits of using digital diplomacy; and the risks of digital diplomacy. It is concluded that it is no longer possible to put our heads in the sand. This is due to the fact that digital diplomacy, with its potential, is a reality in the digital era, and what remains is to consider how to make use of it to the fullest extent possible.

1 Holmes, M. 'What is e-Diplomacy?' Paper presented at 7th European Consortium for Political Research General Conference, Bordeaux, 2013.

${ }^{2}$ Van Ham, P. Social Power in International Relations, London, Routledge, 2010.

3 Holmes, M. 'What is e-Diplomacy?' Paper presented at 7th European Consortium for Political Research General Conference, Bordeaux, 2013.

\section{$(891)$}


${ }^{4}$ Manor, I. 'In light of Digital Diplomacy - are we in need of new communication models?' Exploring Digital Diplomacy, 17 February 2015.

${ }^{5}$ Manor, I. 'Between Digital Diplomacy and Diplomacy 2.0', Public Diplomat website, 3 February 2015. See also: Manor. I., R. Kampf and E. Segev, 'Digital Diplomacy 2.0? A Cross-National Comparison of Public Engagement in Facebook and Twitter', The Hague Journal of Diplomacy 10/4 (2015), forthcoming.

${ }^{6}$ George Haynal, Michael Welsh, Louis Century \& Sean Tyler The Consular Function in the 21st Century, Munk School of Global Affairs, University of Toronto, 27 March 2013. Underlining added

${ }^{7}$ Ministry of Foreign Affairs of Finland, 'Did the world surprise you, too?

http://formin.finland.fi/public/Print.aspx? contentid=317925\&node $\underline{\mathrm{id}=15148 \& \text { culture }=\text { en-US\&contentlan }=2}$

${ }^{8}$ Conference report, Contemporary consular practice; trends and challenges, 3-5 September 2013, Wilton Park.

${ }^{9}$ Mickoleit, A., (2014) 'Social media use by governments: a policy primer to discuss trends, identify policy opportunities and guide decision makers', OECD Working Papers on Public Governance no 26, OECD Publishing.

$<$ http://dx.doi.org/10.1787/5jxrcmghmk0s-en $>$

10 MacAskill, E. 'Army sends tweet brigade into battle', The Guardian, 31 January 2015.

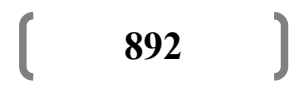


Diplomacy in the Digital Age

Dr. Amany Essam Mohammed

مجلة وادي النيل للاراسات والبحوث الإنسانية والاجتماعية والتربوية (مجلة علمية محكمة)

${ }^{11}$ Karl Deutsch, The Analysis of International Relations, 3rd ed., Englewood Cliffs (NJ), Prentice Hall, 1988, 87.

12 J. Spanier and D. Wendzel, Game Nations Play, CQPress, 1996, p. 89.

139 Hans Morgenthau, Politics Among Nations. The Struggle for Power and Peace, 5th ed., NY, Alfred A. Knopf, 1973, p. 74; see also K. J. Holsti, International Politics (Englewood Cliffs (NJ): Prentice Hall, 1992, p. 116.

${ }^{14}$ Mark Leonard and Catherine Stead, Public Diplomacy, Foreign Policy Center, London, 2002, pp. 9-10.

${ }^{15}$ Evan H. Potter, Special Advisor (communications) to the Policy Planning Division of the DFAIT, 'Canada and the New Public Diplomacy', Discussion Paper in Diplomacy, Published by Spencer Mawby, University of Leicester, Netherlands Institute of International Relations, 2002, p.19.

${ }^{16}$ U.S. State Department, U.S. Department of State Strategic Plan (2000), op. cit. 10 Secretary of State Madeleine K. Albright, Remarks at Dinner for White House Conference on Diplomacy and Culture, U.S. Department of State, November 27, 2000, p.8.

17 Germany - GFMOFA, 'Strategy for the immediate future', GFMOFA, available @ http://www.auswaertigesamt.de/www/en/aussenpolitik/kulturpolitik/grundsaetze/index_ht $\mathrm{ml}$ 
${ }^{18}$ Warren P. Strobel, "The Media: Influencing Foreign policy in the Information Age", U.S. Foreign Policy Agenda, March 2000; US State Department, 'About the Office of International Information Programs, Office of International Information Programs, available@http://usinfo.state.gov/about/index.htm.

${ }^{19}$ U.S. State Department, U.S. Department of State Strategic Plan (2000), op. cit.

${ }^{20}$ Liz Noble and Mark Leonard, "Being Public: How diplomacy will need to change to cope with the information society", iMP Magazine, July 23, 2001, available @ http://www.cisp.org/imp/july_2001/07_01leonard.htm

${ }^{21}$ Mark Leonard and Catherine Stead, Public Diplomacy, Foreign Policy Center, London, 2002, p.47.

22 Andrew Latham, "Theorizing the Landmine Campaign: Ethics, Global Cultural Scripts, and the Laws of War", in Rosalind Irwin dir., Ethics and Security in Canadian Foreign Policy, Vancouver, UBC Press, 2001.

23 UK British Council, 'Public Diplomacy Strategy', BC, 2001 available@ http://www.ukinbangladesh.org/pds2001.doc

24 US State Department, Annual Report on Military Power of People's Republic of China - Report to Congress, released by the US State Department's Bureau of International Information Program (IPP), available http:/usinfo.state.gov/regional/ea/uschina/dodrpt00.htm, 2000.

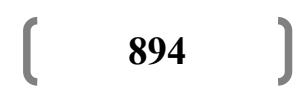




\section{Diplomacy in the Digital Age}

Dr. Amany Essam Mohammed

مجلة وادي النيل للاراسات والبحوث الإنسانية والاجتماعية والتربوية (مجلة علمية محكمة)

${ }^{25}$ India Ministry of Foreign Affairs, International Affairs Strategy of India, MEADEV 2002, available @ http:/www.meadev.nic.in/.

${ }^{26}$ Il Direttore Generale per la Promozione e Cooperazione Culturale Francesco Aloisi de Larderel: 'La promozione della cultura e della lingua italiane all'estero è strettamente legata ai rapporti politici ed economici che l'Italia mantiene con tutte le aree del mondo'; Italia - Ministry of Foreign Affairs, Francesco Aloisi de Larderel, Il Direttore Generale per la Promozione e Cooperazione Culturale, Promozione e Cooperazione Culturale, Presentazione dell'attività della Direzione Generale per la Promozione e la Cooperazione Culturale, available@ http://www.esteri.it/eng/foreignpol/index.htm.; Turkish Ministry of Foreign Affairs, Functions of the Directorate General of Cultural Affairs and its Activities for the Years 1998-1999, available@ @ttp://www.mfa.gov.tr/grupa/ao/01.htm; see also P.C. Pahlavi, "La diplomatie culturelle à l'ère de l'interdépendance globale: la Turquie à la recherche des éléments fédérateurs de l'identité panturque". Revue Études Internationales, volume XXXIII, no 2, juin 2002; Hamidreza Assefi, op. cit., p. 8.

27 Constantin Von Barloeven, "La Culture, Facteur de la Realpolitik", Le Monde Diplomatique, Novembre 2001, pages 22 et 23 . 
${ }^{28}$ Pierre Pahlavi, "Cyber-Diplomacy: A New Strategy of Influence”, Paper presented to the Canadian Political Science Association General Meeting 2003 Halifax, Nova Scotia May 30, 2003.

${ }^{29}$ Liz Noble and Mark Leonard, "Being Public: How diplomacy will need to change to cope with the information society", iMP Magazine, July 23, 2001, available @ http://www.cisp.org/imp/july_2001/07_01leonard.htm.

${ }^{30}$ Germany - GMOFA, op. cit.

${ }^{31}$ U.S. State Department, U.S. Department of State Strategic Plan (2000), op. cit.

${ }^{32}$ Ibid.

33 Lorne W. Craner, Assistant Secretary of State US State Department, Bureau of Democracy, Human Rights and Labor, Human Rights Reports 2001, DHRL; see also Interview with German State Secretary Dr Pleuger in Deutschland, April 2000.

${ }^{34}$ U.S. State Department, U.S. Department of State's Strategic Plan (2000), op. cit.

${ }^{35}$ Michael W. Doyle, "A Liberal View: Preserving and Expending the Liberal Pacific Union", in John A. Hall and T.V. Paul, eds., International Order and the Future of World Politics, Cambridge, Cambridge University Press, 1999, p. 45.

${ }^{36}$ Immanuel Kant, Perpetual Peace and Other Essays, Translated, with Introduction by Ted Humphrey, Indianapolis, Hackett, 1983, p. $370-72$. 
Diplomacy in the Digital Age

Dr. Amany Essam Mohammed

مجلة وادي النيل للاراسات والبحوث الإنسانية والاجتماعية والتربوية (مجلة علمية محكمة)

${ }^{37}$ U.S. State Department, U.S. Department of State's Strategic Plan (2000), op. cit.

38 U.S. Rep. Henry J. Hyde (R- IL), chairman of the House International Relations Committee, "Speaking to Our Silent Allies, The Role of Public Diplomacy in U.S. Foreign Policy", address delivered to the Council on Foreign Relations, 17 June 2002 .

39 Silvio Berlusconi, Italia's Prime Minister and Acting Foreign Minister, Speech to the Chamber of Deputies, 25 September 2002, available@ @ttp://www.esteri.it/eng/foreignpol/index.htm.

${ }^{40}$ U.S. State Department, U.S. Department of State's Strategic Plan (2000), op. cit.

${ }^{41}$ Kinsman, J. \& Bassuener, K. (2010). A Diplomat's Handbook for Democracy and Development Support. Washington: Council for a Community of Democracies, p. 38.

${ }^{42}$ Kalathil, S., ed. (2013). Diplomacy Development and Security in the Information Age. Washington: Georgetown University, pp. 36-39.

${ }^{43}$ Kolodziej, A., E. (2005). Security and International Relations. UK: Cambridge University Press, p.87.

${ }^{44}$ Collins, A. (2009). Studime Bashkëkohore të Sigurisë. Tiranë: UET Press,p.25. 
${ }^{45}$ Ruffini, B., P. (2017). Science and Diplomacy: A New Dimension of International Relations. Switzerland: Springer International Publishing, p.25.

46 Wikinson, P. (2007). International Relations: A Very Short Introduction. UK: Oxford University Press, p.15.

47 Booth, K. (2007). Theory of World Security. UK: Cambridge University Press, p.54.

${ }^{48}$ Inoguchi, T. \& Marsh, I., ed. (2008). Globalisation, Public Opinion and the State: Western Europe and East and Southeast Asia. New York: Routledge, pp.56-57. 